\title{
Biochemical Fingerprints of Some Endemic Plants Growing in Gypsum Soils: Attenuated Total Reflection-Fourier Transform Infrared (ATR-FTIR) Spectroscopic Study
}

\author{
Aysenur Kayabas ${ }^{1}$ (D), Ertan Yildirim ${ }^{2}$ \\ 'Çankırı Karatekin University, Faculty of Science, Department of Biology, Çankırı, Turkey \\ 2Gazi University, Faculty of Science, Department of Chemistry, Ankara, Turkey
}

ORCID IDs of the authors: A.K. 0000-0003-3555-4399; E.Y. 0000-0002-4083-3408

Please cite this article as: Kayabas A, Yildirim E. Biochemical Fingerprints of Some Endemic Plants Growing in Gypsum Soils: Attenuated Total Reflection-Fourier Transform Infrared (ATR-FTIR) Spectroscopic Study. Eur J Biol 2021; 80(2): 97-106. DOI: 10.26650/EurJBiol.2021.1005264

\begin{abstract}
Objective: The aim of this study is to reveal the biochemical fingerprints of Achillea gypsicola Hub.-Mor., Alyssum nezaketiae Aytaç \& H.Duman, Onobrychis germanicopolitana Hub.-Mor. \& Simon, Paracaryum paphlagonicum (Bornm.) R.Mill and Thymus leucostomus Hausskn. et Velen. grown in extreme gypsum habitats with the Attenuated total reflection-Fourier transform infrared (ATR-FTIR) technique, and to determine the differences and densities of organic and inorganic compounds reflected by extreme environmental conditions.
\end{abstract}

Materials and Methods: Using ATR-FTIR spectra, the chemical content of endemic plants was elucidated. In addition, band intensities were calculated using the ATR-FTIR spectra. By doing soil analysis, the physical and chemical properties of the regions where the plants grow were tried to be understood.

Results: As a result of the detailed analysis of the ATR-FTIR spectra, it was understood that the chemical substance content was similar, but the amount was different from plant to plant, regardless of soil. These results showed that the same plant species contain different amounts of chemicals.

Conclusion: FTIR spectroscopy is an effective tool that reveals the biochemical fingerprints of plants by contributing to the determination of organic and inorganic compounds in the structures of plants grown on gypsum substrates. Our results provided evidence for the presence of sulfate from organic molecules and the presence of gypsum and calcium oxalate from inorganic compounds. This study, which is the first to determine the biochemical fingerprints of plants growing in gypsum habitats in Turkey, will enrich the generality of future studies and the interpretation of other gypsophytes in the world.

Keywords: ATR-FTIR, band intensities, Çankırı, fingerprints, gypsophyte, soil structure

\section{INTRODUCTION}

Gypsum-specific plants, called gypsophiles, have a high affinity for gypsum soils (1). It is still not clear why gypsophiles have a higher affinity for gypsum soils. Parent material, also called substrate, is an important abiotic factor in biodiversity (2). The gypsum and salt-rich outcrops are the best model examples of an edaphic island-like habitat and contain rare and endemic species, many of which are threatened (3). Plant species that grow in gypsum soils with high calcium and sulfur ratios and have high affinity for gypsum are also called edaphic endemics (4). Plants grown in gypsum habitats are named specialist plants called gypsophiles and generalist plants called gypsovags according to their affinity for gypsum (5). These habitats are natural wonders of biogeological heritage that contain rare and endemic species. Considering the distribution of gypsum in the world (6), Turkey is one of the important countries. Gypsum areas cover a large area of the Cen- 
tral Anatolia region (7), and the diversity of endemic plants in these areas is also quite high.

Gypsum soils present the extreme physical and chemical characteristics of plant species with important adaptations, such as gypsophilic flora (8). Habitats with high gypsum and salt content are in the position of disjunct areas that are described as ecologic islands in regions with arid and semi-arid climatic conditions (3, 9-11). Studies on the determination of ecological strategies based on phytochemical analyzes of plants grown in gypsum soils have attracted a lot of attention recently. However, these studies are based on more floristic diversity and elemental composition analyses. Most of these studies have been carried out by phytochemical analysis of the leaf part of the plant. Phytochemical content analysis in other organs of plants is not sufficient. Since the results in phytochemical analyses are more general, biochemical fingerprinting techniques that allow the identification of functional chemical groups of plants are needed to know whether they are the same as comprehensive analyses of plant biochemistry. Approaches based on the FTIR technique are important in our country, which has a wide range of gypsum habitats, in terms of shedding light on the biochemical and physiological adaptations developed by plants to survive in harsh environments. This study is based on the first biochemical fingerprinting technique to help understand the life of five endemic plants growing on gypsum substrates in harsh environments which have similar affinity to gypsum.

Attenuated Total Reflection-Fourier Transform Infrared (ATRFTIR) spectroscopy has popular biological applications, from protein content determination to imaging cancer tissues (1214). FTIR spectroscopy, which performs chemical analysis of biological samples in a practical, cost-effective, and non-destructive way, is a valuable tool in biochemical fingerprinting determination and allows the identification of both organic and inorganic compounds (15-18). Although the use of FTIR spectroscopy is increasing day by day and it is widely used in plants, its application to edaphic endemism studies is very rare in the literature. Palacio et al. reported the similarities and differences of the groups by comparing the FTIR results of the plant groups that developed different ecological strategies grown on gypsum (19). Nikalje et al. elucidated the salt stress responses of the roots and leaves of the halophyte Sesuvium portulastrum (L.) L. by determining the FTIR profile (20). Calcium oxalate crystals that occur as intravacuolar deposits (21) are observed in most plants growing in gypsum habitats because of adaptation to extreme conditions (22). Calcium oxalate, calcium carbonate, and amorphous silicas are the most common biominerals (23). FTIR spectroscopy also reveals the biochemical activity of the organism and the presence of biominerals (24) formed because of local accumulation of elements in the extreme environment in which it lives (23).

Approaches based on the FTIR technique are important in our country, which has a wide range of gypsum habitats, in terms of shedding light on the biochemical and physiological adap- tations developed by plants to survive in harsh environments. This study is based on the first biochemical fingerprinting technique that will help to understand the life of five endemic plants growing on gypsum substrates in harsh environments.

The aim of this study is to reveal the biochemical fingerprints of Achillea gypsicola Hub.-Mor., Alyssum nezaketiae Aytaç \& H.Duman, Onobrychis germanicopolitana Hub.-Mor. \& Simon, Paracaryum paphlagonicum (Bornm.) R.Mill and Thymus leucostomus Hausskn. et Velen. grown in extreme gypsum habitats with the ATR-FTIR technique, and to determine the differences and densities of organic and inorganic compounds reflected by extreme environmental conditions. The biochemical fingerprints of the plants were revealed for the first time by analyzing the root, stem, and leaf parts of five endemic gypsophytes specific to gypsum substrates with the help of ATR-FTIR spectroscopy. In addition, physical and chemical analyses of the soil where the plants were grown were done, and the results of the ATR-FTIR of the plants were correlated with some analysis results of the soil.

\section{MATERIALS AND METHODS}

\section{Collection of Plant Species and Study Area}

Five gypsophyte plants were selected for analysis: Achillea gypsicola Hub.-Mor., Alyssum nezaketiae Aytaç \& H.Duman, Onobrychis germanicopolitana Hub. -Mor. \& Simon, Paracaryum paphlagonicum (Bornm.) R.Mill and Thymus leucostomus Hausskn. et Velen (Figures 1A, 2A, 3A, 4A, 5A). All of them were taken in gypsum soils in May-June 2021.

Plants were taken as whole individuals from gypsum habitats. The plant samples brought to the laboratory were first rinsed with tap water and then purified from dirt and soil. Taxonomic identifications of gypsophytes were done according to the Flora of Turkey and the East Aegean Islands $(25,26)$. Also, the categories of A. gypsicola, A. nezaketiae, O. germanicopolitana, $P$. paphlagonicum, and T. leucostomus were evaluated according to the IUCN Red Data Book (27). The IUCN categories of the studied species are VU, CR, EN, LR (cd), and VU, respectively. All the examined specimens are preserved in Çankırı Karatekin University, Department of Biology as a personal collection.

This study was conducted in gypsum areas between the Aşağıpelitözü and Balıbağı villages (750-900 m a.s.l., 40³0' N, $33^{\circ} 42^{\prime}$ Çankırı, East of Central Anatolia, Turkey). The study area, which is under the influence of a semi-arid Mediterranean climate, is located within the Irono-Turan phytogeographic region. Vegetation was composed predominantly of shrubs, subshrubs, grasses and steppe plants, like, Achillea phrygia Boiss. \& Balansa, Asperula bornmuelleri Velen, Asperula cankiriense B.Şahin \& Sağıroğlu, Bromus tomentellus Boiss., Campanula pinnatifida Hub.-Mor., Genista albida Willd., Gypsophila parva Barkoudah, Gypsophila eriocalyx Boiss., Helianthemum germanicopolitanum Bornm., Paracaryum ancyritanum Boiss., Salvia absconditiflora (Montbret \& Aucher ex Benth.) Greuter \& Burdet and Teucrium polium L. 


\section{ATR-FTIR Spectroscopic Analysis}

The infrared spectra of dried roots, stems and leaves were obtained by ATR-FTIR spectroscopy, model Thermo Nicolet 6700, supplied by OMNIC and recorded at room temperature in the wavenumber range from 400 to $4000 \mathrm{~cm}^{-1}$ at a resolution of 4 $\mathrm{cm}^{-1}$ and 32 scans. The intensities of the bands that could be determined and measured in the ATR-FTIR spectra were calculated with the help of the OMNIC software.

\section{Soil Analyses}

Soil samples were taken from a depth of $0-20 \mathrm{~cm}$ to characterize the substrate on which the gypsophytes were grown. After the soil samples were brought to the laboratory, they were dried at room temperature. Air-dried soil samples are passed through a $2 \mathrm{~mm}$ mesh sieve and stone, etc. The materials were removed and made ready for analysis. Soil samples taken from the study area were analyzed according to the following methods. The electrical conductivity (EC) was measured with a glass electrode EC-meter in the soil-water extract prepared at a ratio of 1:1 (28) and the soil reaction $(\mathrm{pH})$ were measured with a $\mathrm{pH}$-meter with a glass electrode in the soil-water extract prepared at a ratio of 1:2.5 (29). Exchangeable cations ( $\mathrm{Ca}, \mathrm{Mg}, \mathrm{Na}$ and $\mathrm{K}$ ) were determined by saturating with $1 \mathrm{M}$ ammonium acetate at $\mathrm{pH} 7$ (30). The percentage of gypsum content in the soil was determined gravimetrically by comparing samples dried at $60^{\circ} \mathrm{C}$ and $105^{\circ} \mathrm{C}$ (31).

\section{RESULTS}

The results of the ATR-FTIR spectra for the vegetative organs of the A. gypsicola, A. nezaketiae, O. germanicopolitana, $P$. paphlagonicum and T. leucostomus are summarized. The frequencies and assignments of the identified main peaks are given in Table 1. The presence of bands belonging to functional groups provided important information about the chemical composition of these specialist plants that can survive in harsh gypsum habitats.

The S-O bending functional group in the gypsum compound was detected at 669 and $600 \mathrm{~cm}^{-1}$, and the $\mathrm{O}-\mathrm{H}$ stretching functional group was detected broadly at $3000-3500 \mathrm{~cm}^{-1}$. The $\mathrm{S}-\mathrm{O}$ bending functional group in the sulphates compound was detected at $680-630 \mathrm{~cm}^{-1}$ and $900-1180 \mathrm{~cm}^{-1}$. The C-O plane bending functional group in the calcium carbonate compound was detected at 720 and $875 \mathrm{~cm}^{-1}$. The $\mathrm{C}-\mathrm{O}$ stretching bending functional group, which is also found in the calcium oxalate compound, was detected at 1318 and $1580-1680 \mathrm{~cm}^{-1}$. In addition, another functional group in the calcium oxalate compound, $\mathrm{COO}^{-}$bending, was determined at $775 \mathrm{~cm}^{-1}$. The functional band of long chain (>C4) alkane structures was seen at $730 \mathrm{~cm}^{-1}$. The band of aromatic $\mathrm{CH}_{2}$ functional groups of lignin compound is at $830 \mathrm{~cm}^{-1}$, the band of lignin backbone is at $1185-1290 \mathrm{~cm}^{-1}$, the functional band for lignin-phenolic backbone containing aromatic carbons is at 1505$1510 \mathrm{~cm}^{-1}$, lignin and other bands belonging to aromatic double bonds determined to belong to aromatic structures were detected at $1580-1680 \mathrm{~cm}^{-1}$. The broad band determined at approximately $950-1100 \mathrm{~cm}^{-1}$ for polysaccharides, silicates, sulphates, and phosphates represents the functional groups found in these species. Bands defining esters were detected at 1185-1290 and 1730-1735 $\mathrm{cm}^{-1}$, respectively. Bands of phenolic (lignin) and aliphatic structures, carboxylate/carboxylic structures were seen at $1380-1480 \mathrm{~cm}^{-1}$. The plane (amide-II) band of $\mathrm{N}-\mathrm{H}$ in proteinaceous origin was detected at $1555 \mathrm{~cm}^{-1}$. The bands belonging to the carbonyl functional group of the carboxylic acid groups were determined at $1707-1703 \mathrm{~cm}^{-1}$. Bands belonging to aliphatic $\mathrm{CH}_{2}$ groups in fats, wax and lipids were seen at $2850-2920 \mathrm{~cm}^{-1}$. Hydroxyl bands in cellulosic structures were determined at 3000$3600 \mathrm{~cm}^{-1}$. The presence of bands belonging to functional groups provided important information about the chemical content of gypsum species (Table 1).

The band areas of the bands at 900-1180, 1185-1290, 1380$1480,1580-1680,2850-2920$ and $3000-3500 \mathrm{~cm}^{-1}$, which can be determined for each plant species and can be measured, were calculated. The band intensities at $900-1180 \mathrm{~cm}^{-1}$ for the root, stem, and leaf parts of $A$. gypsicola were calculated as 3125 , 2280 and 2900 a.u. (arbitrary units), respectively. It was determined as 125, 10 and 100 a.u. for the bands at $1185-1290 \mathrm{~cm}^{-1}$. Band intensities at $1380-1480 \mathrm{~cm}^{-1}$ were measured at 315,150 and 190 a.u. Intensities in the band range of $1580-1680 \mathrm{~cm}^{-1}$ were calculated as 360, 280 and 490 a.u. The areas of the bands at $2850-2920 \mathrm{~cm}^{-1}$ were found to be 215,250 and $680 \mathrm{a}$.u. The areas of the bands at $3000-3500 \mathrm{~cm}^{-1}$ belonging to the hydroxyl band representing the gypsum were calculated as 2750, 2780 and 2300 a.u., respectively (Figures 1B and C).

Different results were obtained when the band intensities of $A$. nezaketiae were compared with those of $A$. gypsicola. In this context, band intensities were calculated as 2400, 2280 and 4000 a.u. for root, stem, and leaf at $900-1180 \mathrm{~cm}^{-1}$ in $A$. nezaketiae. The band at $1185-1290 \mathrm{~cm}^{-1}$ was observed only in the root with a band with an intensity of 385 a.u., while the intensity of this band could not be detected in the stem and leaves. Band intensities at $1380-1480 \mathrm{~cm}^{-1}$ were calculated as 110, 550 and 500 a.u. The intensities of the bands, which are thought to belong to lignin and other aromatics and observed at $1580-1680 \mathrm{~cm}^{-1}$, were found as 360, 160 and 200 a.u. Band intensities at $2850-2920 \mathrm{~cm}^{-1}$ were calculated as 520, 400 and 335 a.u. Hydroxyl band intensities were found in this plant species in 1880, 2100 and 1850 a.u. (Figures 2B and C).

In the qualitative analysis of the root, stem, and leaf of 0 . germanicopolitana, band intensities at $90-1180 \mathrm{~cm}^{-1}$ were found to be 3400, 245 and 3350 a.u., respectively. Band intensities at $1185-1290 \mathrm{~cm}^{-1}$ were calculated as 140,150 and 180 a.u. The band intensities of the functional groups at 1380-1480 cm were determined as 530, 220 and 360 a.u. The band intensities of the aromatic $C=C$ double bonds at $1480-1580 \mathrm{~cm}^{-1}$ were found to be 850,550 and 420 a.u. Band intensities of symmetric and antisymmetric aliphatic functional groups were calculated as 750,670 and 1280 a.u. The band intensities of the hydroxyl stretch band at $3000-3500 \mathrm{~cm}^{-1}$ were found to be 2850,5025 and 6200 a.u., respectively (Figures 3B and C). 


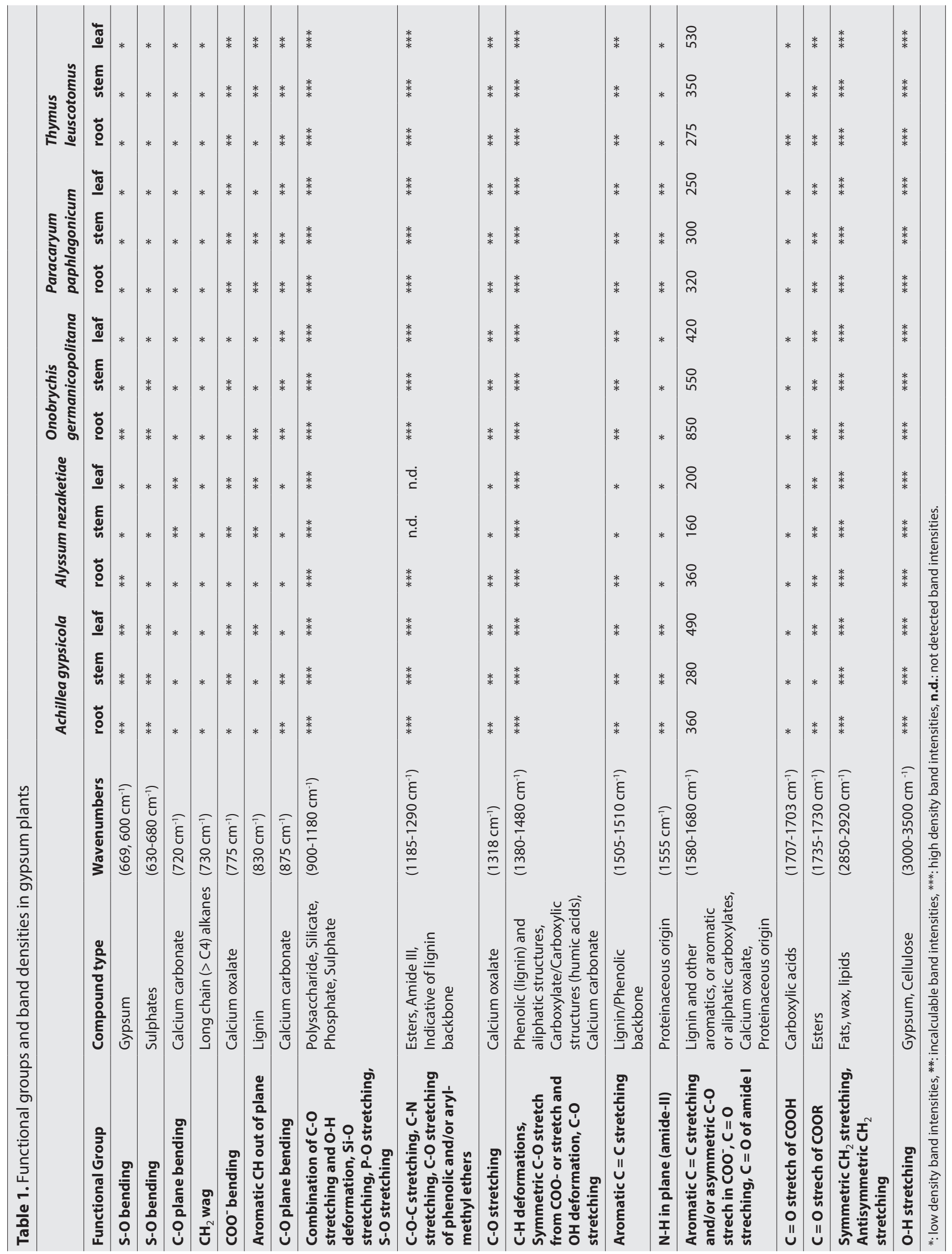



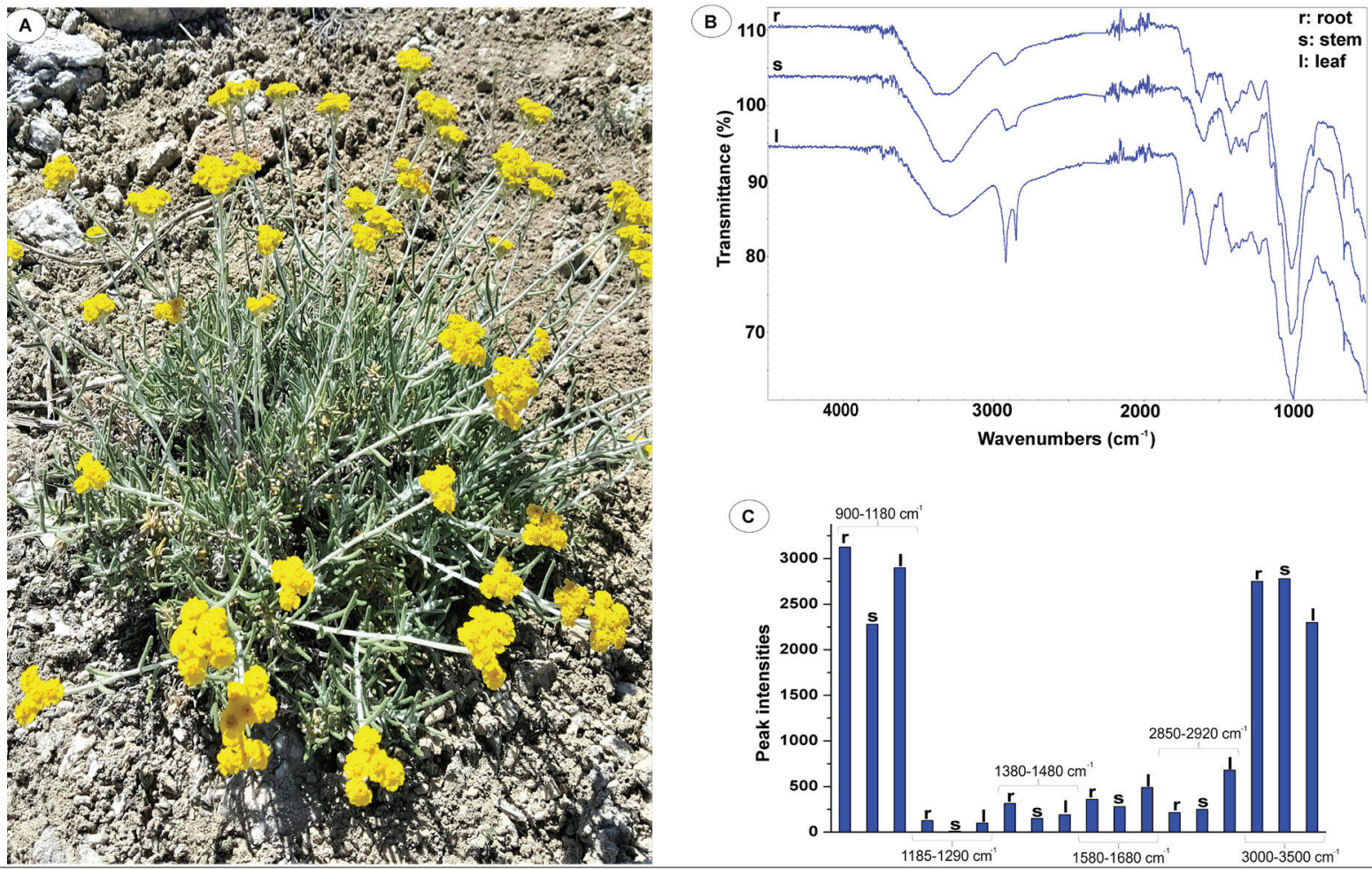

Figure 1. A. Achillea gypsicola habit (from Çankırı province). B. ATR-FTIR spectra of A. gypsicola. C. Graph of band intensities of A. gypsicola.
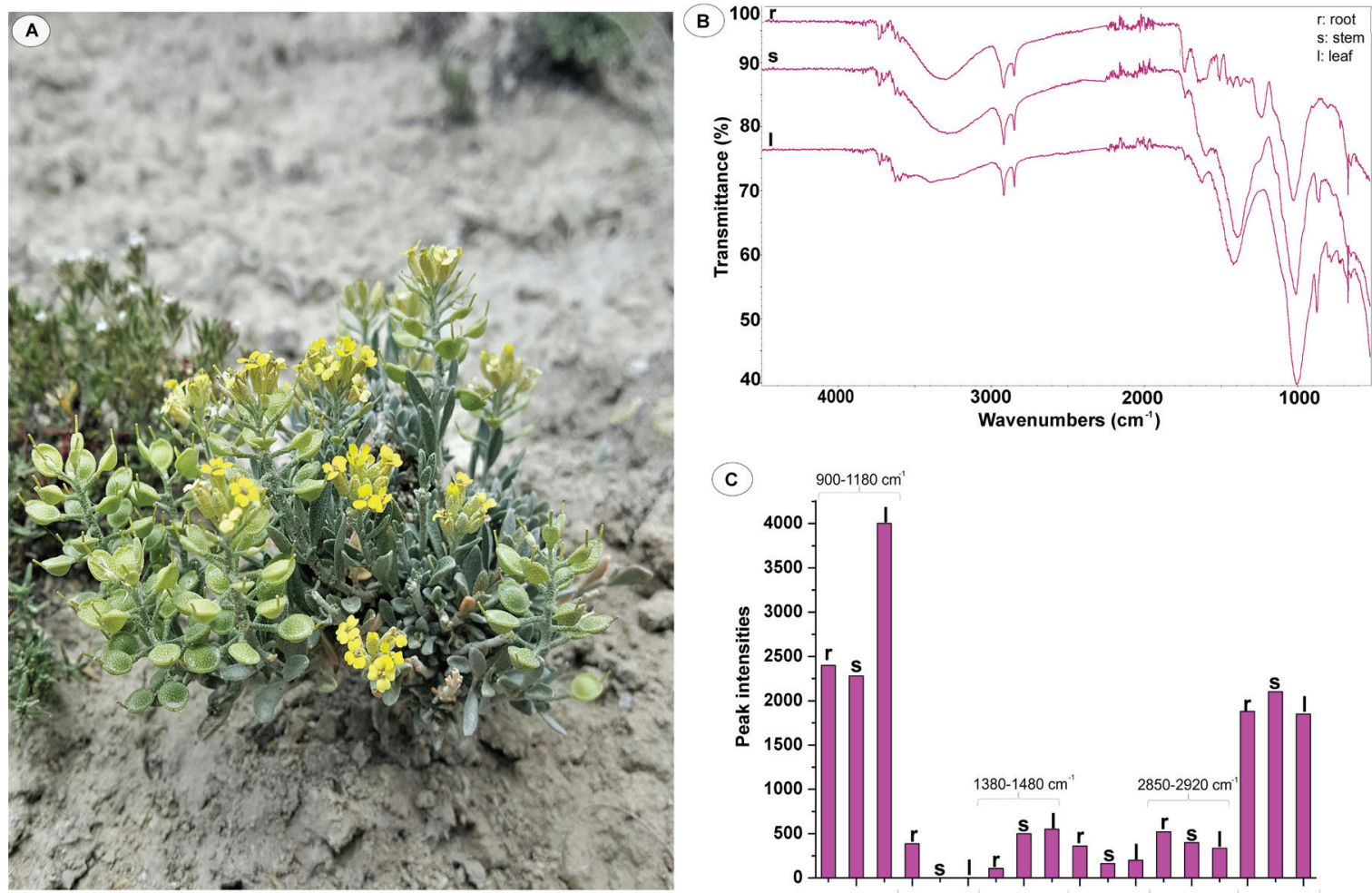

$1185-1290 \mathrm{~cm}^{-1}$

$1580-1680 \mathrm{~cm}$

$3000-3500$

Figure 2. A. Alyssum nezaketiae habit (from Çankırı province). B. ATR-FTIR spectra of A. nezaketiae. C. Graph of band intensities of A. nezaketiae. 

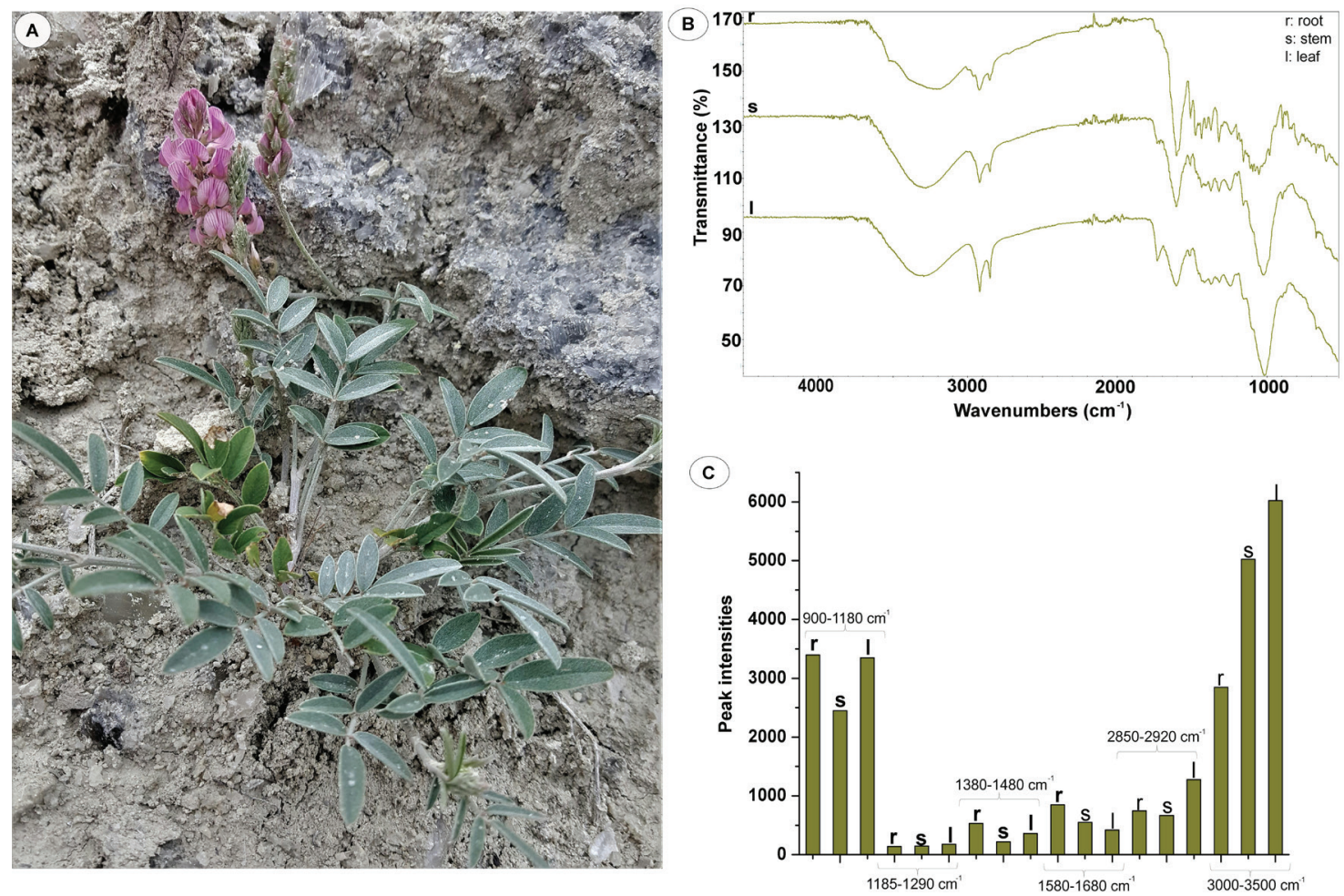

Figure 3. A. Onobrychis germanicopolitana habit (from Çankırı province). B. ATR-FTIR spectra of O. germanicopolitana. C. Graph of band intensities of O. germanicopolitana.

The following data were obtained because of the calculation of the band intensities for the root, stem, and leaf parts of the $P$. paphlagonicum. 3700, 2250 and 2670 a.u. band intensities were determined for the $900-1180 \mathrm{~cm}^{-1}$ band range. For the 1185 $1290 \mathrm{~cm}^{-1}$ range, band intensities were calculated as 275,190 and 110 a.u., respectively. The band intensities of the functional groups at $1380-1480 \mathrm{~cm}^{-1}$ were found to be 210,280 and 56 a.u. The intensities of the bands at $1580-1680 \mathrm{~cm}^{-1}$ were calculated as 320, 300 and 250 a.u. Band intensities of 150, 510 and 521 a.u. were calculated for the band range at $2850-2920 \mathrm{~cm}^{-1}$. The band intensities of the hydroxyl groups of gypsum in the plant species at $3000-3500 \mathrm{~cm}^{-1}$ were found to be 3350, 2400 and 2910 a.u., respectively (Figures $4 \mathrm{~B}$ and $\mathrm{C}$ ).

Finally, the regions and intensities of the bands that can be detected in the ATR-FTIR spectra and whose band intensities can be measured were determined for root, stem, and leaf of $T$. leuscotomus. The band intensities in the broad band at 900-1180 $\mathrm{cm}^{-1}$ were found to be 2500, 2620 and 3000 a.u., respectively. The band intensities of the functional groups at $11850-1290 \mathrm{~cm}^{-1}$ were calculated as 230,50 and 85 a.u. While the band intensities at $1380-1480 \mathrm{~cm}^{-1}$ were calculated as 480 , 120 and 350 a.u., the band intensities at $1585-1680 \mathrm{~cm}^{-1}$ were found as 275,350 and 530 a.u. The intensities of the bands at 2850-2920 cm-1, which are thought to belong to oils, lipids, and waxes, were calculated as 595, 675 and 1250 a.u. The intensities of the broad band at $3000-3500 \mathrm{~cm}^{-1}$ were found to be 4850 , 2550 and 3600 a.u., respectively (Figures 5B and C).
In summary, at the $900-1180 \mathrm{~cm}^{-1}$ band content, the variety of inorganic compounds (silicates, phosphates, and sulphates) is more than organic compounds (polysaccharids). It was determined that the $\mathrm{C}-\mathrm{O}-\mathrm{C}$ stretching, $\mathrm{C}-\mathrm{N}$ stretching, $\mathrm{C}-\mathrm{O}$ stretching of phenolic and/or aryl-methyl ethers bending seen at 1185-1290 $\mathrm{cm}^{-1}$ were very high in terms of organic compounds including esters, amide, and indicative of lignin backbone. It was determined that the $\mathrm{C}-\mathrm{H}$ deformations, symmetric $\mathrm{C}-\mathrm{O}$ stretch from $\mathrm{COO}^{-}$ or stretch and $\mathrm{OH}$ deformation, $\mathrm{C}-\mathrm{O}$ stretching bending seen at $1380-1480 \mathrm{~cm}^{-1}$ were very high in terms of organic compounds including phenolic (lignin) and aliphatic structures and carboxylate/carboxylic structures (humic acids). It was determined that the symmetric and antisymmetric $\mathrm{CH}_{2}$ stretching bending seen at $2850-2950 \mathrm{~cm}^{-1}$ were more abundant in terms of organic compounds including fats, wax, and lipids. It is understood from the band intensities that the roots, stems and leaves of the five gypsophytes, the gypsum inorganic compound belonging to the broad O-H stretching bending seen at $3000-3500 \mathrm{~cm}^{-1}$, are in excess in the ATR-FTIR spectra (Table 1, Figures 1C-5C).

The plant species selected in this study were selected from plants grown in gypsum habitats. Knowing the physical and chemical properties of the substrate, that is, the soil, on which these gypsophytes grow, has helped to understand the extreme conditions under which gypsophytes grow. For this purpose, soil properties such as $\mathrm{pH}$, electrical conductivity (EC), exchangeable $\mathrm{Ca}, \mathrm{Mg}, \mathrm{Ca}, \mathrm{K}$, cation exchange capacity (CEC), exchangeable sodium percentage (ESP), gypsum content (\%) 

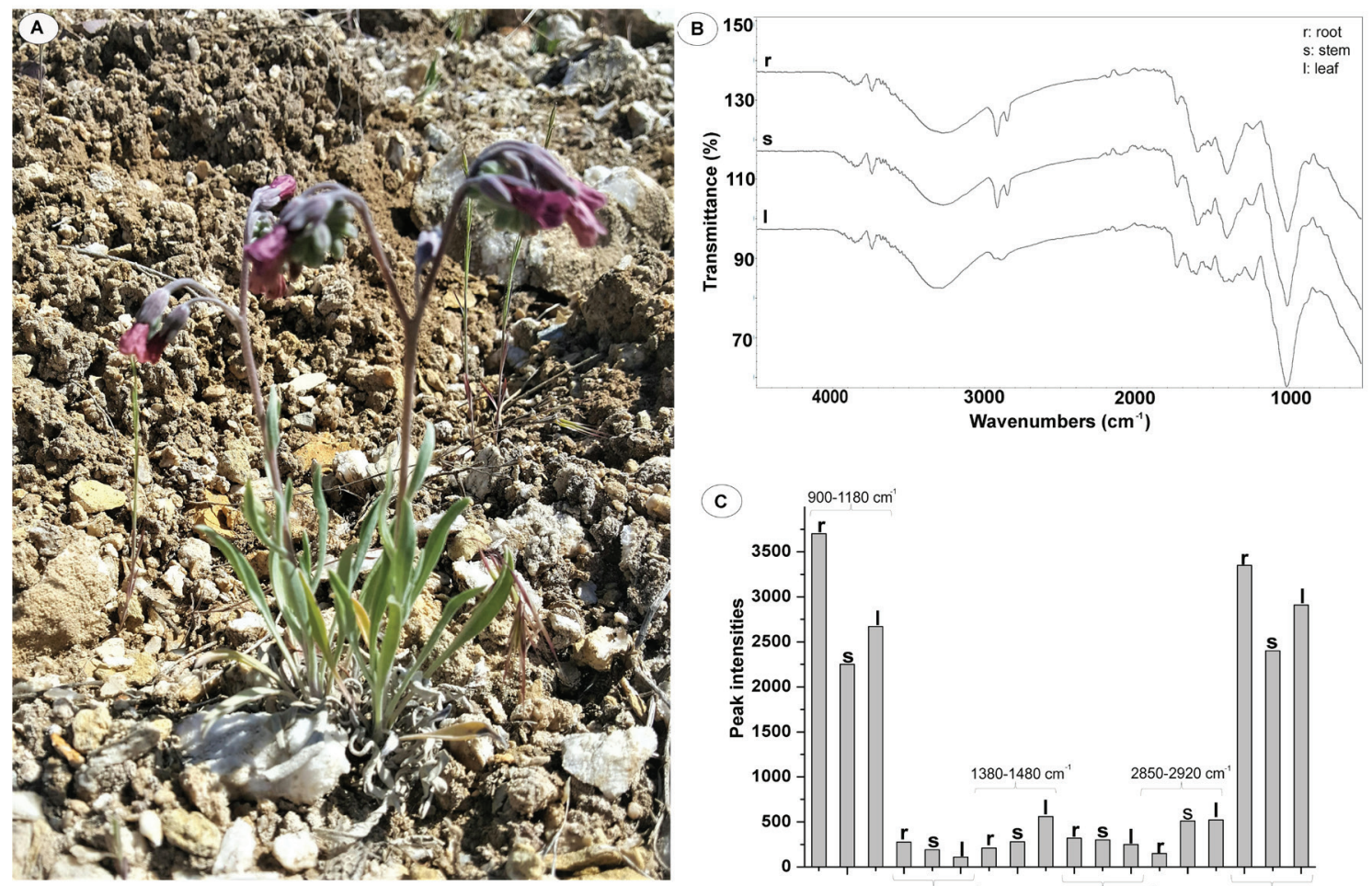

Figure 4. A. Paracaryum paphlagonicum habit (from Çankırı province). B. ATR-FTIR spectra of P. paphlagonicum. C. Graph of band intensities of P. paphlagonicum.
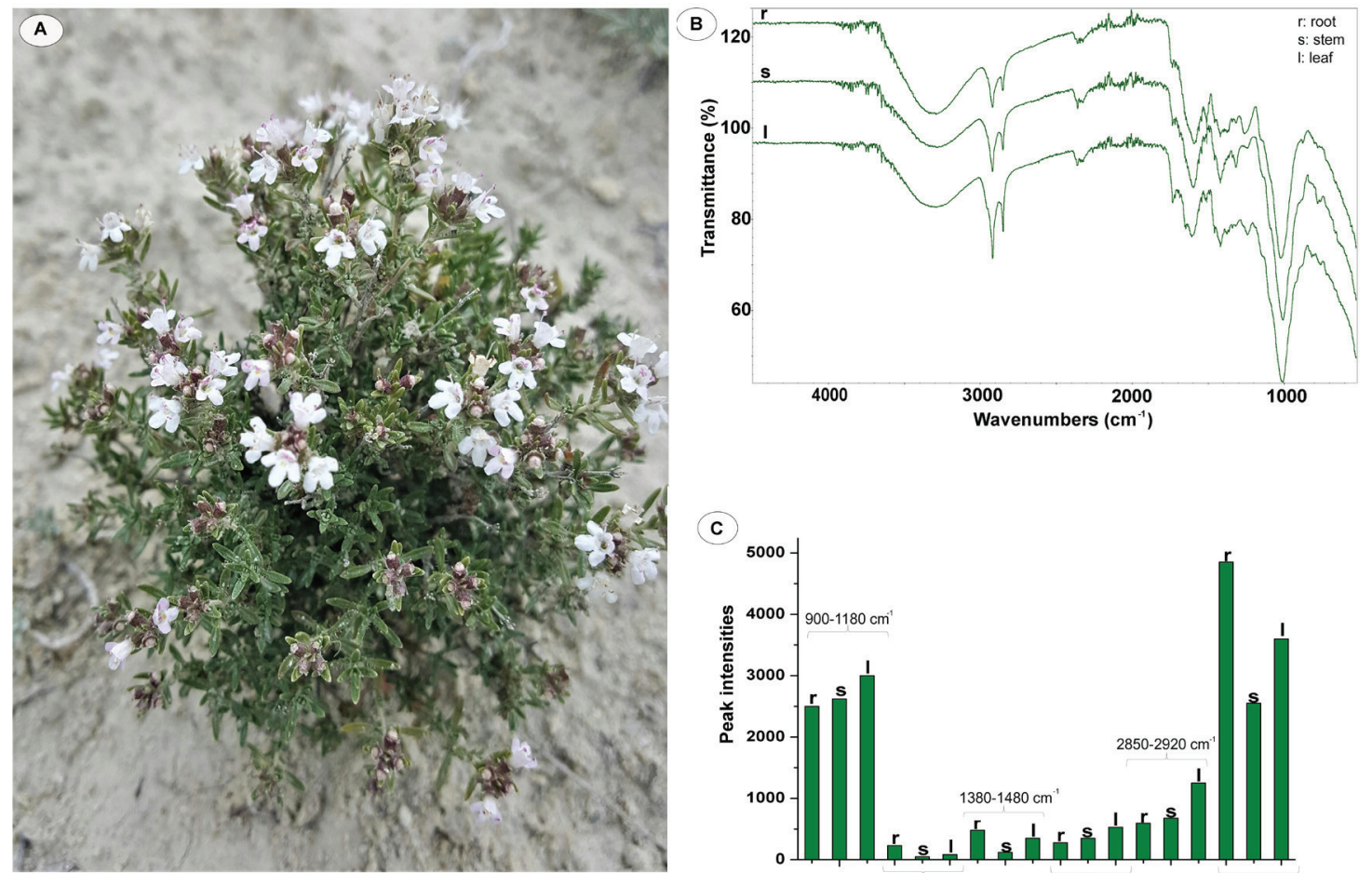

Figure 5. A. Thymus leucostomus habit (from Çankırı province). B. ATR-FTIR spectra of T. leucostomus. C. Graph of band intensities of T. leucostomus. 
were also analyzed (Table 2). According to the soil physical analysis, the $\mathrm{pH}$ is 7.76 and the EC value is $2.76 \mathrm{dS} \mathrm{m}^{-1}$. Exchangeable $\mathrm{Ca}, \mathrm{Mg}, \mathrm{Ca}, \mathrm{K}$ values are 27.04, 4.33, 1.09 and $0.41 \mathrm{meq} / \mathrm{L}$, respectively and CEC is $26.81 \mathrm{meq} / 100 \mathrm{~g}$. The ESP, gypsum values are 7.64 and $68 \%$, respectively.

\begin{tabular}{ll}
\hline Table 2. Main soil characteristics $(n=3)$ & \\
\hline $\mathrm{pH}$ & 7.76 \\
\hline $\mathrm{EC}\left(\mathrm{dS} \mathrm{m}{ }^{-1}\right)$ & 2.76 (very saline) \\
\hline Exchangeable $\mathrm{Ca}(\mathrm{meq} / \mathrm{L})$ & 27.04 \\
\hline Exchangeable $\mathrm{Mg}(\mathrm{meq} / \mathrm{L})$ & 4.33 \\
\hline Exchangeable $\mathrm{Na}(\mathrm{meq} / \mathrm{L})$ & 1.09 \\
\hline Exchangeable K (meq/L) & 0.41 \\
\hline CEC (meq/100 g) & 26.81 \\
\hline ESP $(\%)$ & 7.64 \\
\hline Gypsum $(\%)$ & 68 \\
\hline
\end{tabular}

\section{DISCUSSION}

The functional groups and band intensities of the root, stem, and leaf parts of five different gypsophiles were measured by ATR-FTIR. The functional groups of A. gypsicola, A. nezaketiae, $O$. germanicopolitana, P. paphlagonicum, and T. leucostomus, endemic to gypsum soils, were similar. Nedyalkova et al. detected that the $\mathrm{S}-\mathrm{O}$ bending band at $611 \mathrm{~cm}^{-1}$ and showed similar results in this study as it was seen at $605-610 \mathrm{~cm}^{-1}$ in gypsum plants (32). Ashfag et al. recorded the wave number of the S-O bending band as $669 \mathrm{~cm}^{-1}$ in sulfates, and the related band was observed at $665-670 \mathrm{~cm}^{-1}$ in this study (33). Jha et al. determined that the S-O stretching vibrations in sulfates at $1100-1200 \mathrm{~cm}^{-1}$ and reported that the band width and density increased with the overlapping of each band in plants (34). In the literature, the band of aromatic $\mathrm{CH}_{2}$ functional groups of lignin is at $\sim 830 \mathrm{~cm}^{-1}$, the band of lignin backbone is at $\sim 1185-1290 \mathrm{~cm}^{-1}$, the functional band for lignin-phenolic containing aromatic carbons is at $\sim 1505-1510 \mathrm{~cm}^{-1}$, lignin and other bands belonging to aromatic double bonds determined to belong to aromatic structures were detected at $\sim 1580-1680 \mathrm{~cm}^{-1}(19,35,36)$. Within the scope of this study, results compatible with the literature were obtained for the wavelengths mentioned in the ATR-FTIR spectra. Palacio et al. reported the presence of sulfates, phosphates, silicates, and polysaccharides at $1150-950 \mathrm{~cm}^{-1}$ in the ATR-FTIR spectra of gypsum plants (19). In this study, the broad band observed at $1200-950 \mathrm{~cm}^{-1}$ was attributed to the functional groups of these species. Since the functional bands of silicate, sulfate, phosphate, and polysaccharides of plant species came to the same spectrum region, the band was seen as very broad at 950$1200 \mathrm{~cm}^{-1}$. In the literature, hydroxyl bands of cellulose containing structures with broad hydroxyl bands have a broad band at $3000-3500 \mathrm{~cm}^{-1}$ (37). The broad band of cellulosic groups found in plants is due to dense hydroxyl groups. The presence of bands belonging to functional groups provided important information about the chemical content of gypsum plants.

In this study, the presence of gypsum, one of the inorganic compounds, is observed in the vegetative organs of gypsophytes. Palacio et al. reported the presence of gypsum inorganic compound in the leaves of wide gypsophiles in their FTIR spectroscopic studies with gypsophiles and gypsovags (19). The presence of gypsum compound is compatible with studies $(38,39)$ specific to Turkey on the phytochemical compositions (as total ash, Ca, and S) of gypsum plants. Duvigneaud and Denaeyer-DeSmet suggested that $\mathrm{S}$ accumulates in the form of calcium sulphate (40), but for the first time Palacio et al. reported the presence of the mineral gypsum (19). The presence of mineral gypsum, which is one of the inorganic compounds from gypsophytes, was reported for the first time in Turkey with this study. He et al., suggested that plants that can survive in gypsum soils form oxalate and sulfate crystals to detoxify excess $\mathrm{Ca}$ and $\mathrm{S}$ (41). The presence of calcium oxalate crystals in the vegetative organs of the plants in this study also supports the results (42). Kayabaş and Kurt reported that Aethionema turcica and $A$. dumanii, which are gypsovags grown on gypsum, contain high $\mathrm{N}$ (39). Palacio et al. have documented that gypsophite Lepidium subulatum has a high $\mathrm{N}$, amino acid, and protein content (43). The presence of protein, peptide, amino acid, and other organic compounds in gypsophytes with high $\mathrm{N}$ content may be due to both $\mathrm{N}$ and $\mathrm{S}$ richness. These results indicate that the phytochemical content of the plant will be in parallel with the results of ATR-FTIR spectroscopy. This study has also documented that the ATR-FTIR technique is a very valuable method for the removal of biochemical fingerprints of plants, since performing these and similar studies with the help of the ATR-FTIR technique provides positive benefits in terms of practicality, time and cost.

When the main soil characteristics summarized in Table 2 are examined, according to the Baize criteria (44), the soil in which the plants grow shows data saline characteristics. About $10 \%$ of the earth is affected by soil salinity and/or sodicity (45). The sum of the exchangeable cations $\left(\mathrm{Ca}^{2+}, \mathrm{Mg}^{2+}, \mathrm{Na}^{+}, \mathrm{K}^{+}\right)$, which significantly affect the physicochemical properties of the soil, is equal to the cation exchange capacity (CEC). The best indicator for calculating this ratio is the calculation of the percent exchangeable sodium (ESP). ESP is the ratio of exchangeable sodium to the CEC of the soil (28). Exchangeable cations significantly affect the physicochemical properties of the soil. The ESP value of the gypsum soil analyzed in this study is $7.64 \%$, and the ESP values are between $0.4-76.5 \%$ when the literature is examined $(27,45$ 52). Hazelton and Murphy described the soils with 6-14\% ESP value as sodium (53). Since the ESP value of the soil analyzed in this study is $7.64 \%$, it also shows high sodium feature. Soils with an ESP value of 6-14\% are considered sodium rich $(53,54)$. High salinity and sodium in the soil negatively affects germination and growth (55). The high percentage of gypsum and sodium content in gypsum soils causes the gypsophytes growing in these habitats to adapt to extreme conditions and thus to spe- 
cialize in gypsum. The presence of gypsum crystals may not be relevant to survival strategy in high gypsum-containing soils. There is no gypsum crystal in every plant that grows in soils with high gypsum content and has high $\mathrm{S}$ content (42).

As a result, FTIR spectroscopy is an effective tool that reveals the biochemical fingerprints of plants by contributing to the determination of organic and inorganic compounds in the structures of plants grown on gypsum substrates. Our results provided evidence of the presence of sulfate from organic molecules and the presence of gypsum and calcium oxalate from inorganic compounds. This study, which is the first to determine the biochemical fingerprints of plants growing in gypsum habitats in Turkey, will enrich to the generality of future studies and the interpretation of other gypsophytes in the world.

\section{CONCLUSION}

Our study investigated the fingerprint properties of endemic gypsophytes which are grown in gypsum habitats by using FTIR techniques. Additionally, the characteristic FTIR spectra of the $A$. gypsicola, A. nezaketiae, O. germanicopolitana, P. paphlagonicum and T. leucostomus were obtained. In this study, the ATR-FTIR technique was applied for the first time in Turkey for plants growing in gypsum habitats. By performing the chemical analysis of the ATR-FTIR spectra of the plants and the gypsum soil in which the plants grew, data on the chemical contents of these plants were obtained to understand their adaptation to extreme habitats. ATR-FTIR spectra were taken from vegetative organs of each plant. With the help of functional groups in the ATR-FTIR spectra, the chemical contents of gypsophytes were elucidated. By calculating the band intensities, it was determined that each plant species and part had different chemical contents. For the first time, within the scope of this study, changes in band intensities were calculated by using ATR-FTIR spectra and information about the chemical content and amount of gypsophytes was presented within the scope of this study. This study will shed light on many future studies on the chemical analysis gypsophytes.

Acknowledgements: The authors would like to thank the Soil, Fertilizer and Water Resources Central Research Institute for performing the soil analyses, and the Gazi University Academic Writing and Research Center for their help and valuable support in the proofreading of this study.

Peer-review: Externally peer-reviewed.

Author Contributions: Conception/Design of study: A.K., E.Y.; Data Acquisition: A.K., E.Y.; Data Analysis/Interpretation: A.K., E.Y.; Drafting Manuscript: A.K., E.Y.; Critical Revision of Manuscript: A.K., E.Y.; Final Approval and Accountability: A.K., E.Y.

Conflict of Interest: The authors declare that they have no conflicts of interest to disclose.

Financial Disclosure: There are no funders to report for this submission.

\section{REFERENCES}

1. Sánchez-Martín R, Querejeta Jl, Voltas J, Ferrio JP, Prieto I, Verdú M, et al. Plant's gypsum affinity shapes responses to specific edaphic constraints without limiting responses to other general constraints. Plant Soil 2021; 462(1): 297-309.

2. Hulshof CM, Spasojevic MJ. The edaphic control of plant diversity. Glob Ecol Biogeogr 2020; 29(10): 1634-50.

3. Bobo-Pinilla J, Salmerón-Sánchez E, Mota JF, Peñas J. Genetic conservation strategies of endemic plants from edaphic habitat islands: The case of Jacobaea auricula (Asteraceae). J Nat Conserv 2021;61:126004.

4. Blanco-Sánchez M, Moore MJ, Ramos-Muñoz M, Pías B, GarcíaFernández $A$, Prieto $M$, et al. Phylogeography of a gypsum endemic plant across its entire distribution range in the western Mediterranean. Am J Bot 2021; 108(3): 443-60.

5. Cera A, Duplat E, Montserrat-Martí G, Gómez-Bolea A, Rodríguez-Echeverría S, Palacio S. Seasonal variation in AMF colonisation, soil and plant nutrient content in gypsum specialist and generalist species growing in P-poor soils. Plant Soil 2021; 1-16.

6. Ramon A, Caselle C, Bonetto SMR, Costanzo D, Alonso EE. Effect of microstructure and relative humidity on strength and creep of gypsum. Rock Mech Rock Eng 2021; 54: 4121-45.

7. Ozel S. Identification and assessment of hazard of development in gypsum karst regions: Examples from Turkey. Tiefenbacher JP, editor. Natural Hazards Risk, Exposure, Response, and Resilience. London: Intech Press; 2019. p. 111-24.

8. Denaeyer-De Smet S. Note on the chemical composition of salts secreted by various gypsohalophytic species of Spain. Bulletin de la Societé Royale de Botanique de Belgique 1970; 103: 273-78.

9. Perez-Garcia FJ, Akhani H, Parsons RF, Silcock JL, Kurt L. Ozdeniz E, et al. A first inventory of gypsum flora in the Palearctic and Australia. Mediterr Bot 2018; 39(1): 35-49.

10. Sánchez AM, Alonso-Valiente P, Albert MJ, Escudero A. How might edaphic specialists in gypsum islands respond to climate change? Reciprocal sowing experiment to infer local adaptation and phenotypic plasticity. Ann Bot 2017; 120(1): 135-46.

11. Martín-Rodríguez I, Escudero A, García-Fernández A. Limited effect of a highway barrier on the genetic structure of a gypsum soil specialist. PeerJ 2021; 9:e10533.

12. Cirrincione M, Saladini B, Brighenti V, Salamone S, Mandrioli R, Pollastro F, et al. Discriminating different Cannabis sativa L. chemotypes using attenuated total reflectance-infrared (ATR-FTIR) spectroscopy: A proof of concept. J Pharm Biomed Anal 2021; 204: 114270.

13. Götz A, Nikzad-Langerodi R, Staedler Y, Bellaire A, Saukel J. Apparent penetration depth in attenuated total reflection Fourier-transform infrared (ATR-FTIR) spectroscopy of Allium cepa L. epidermis and cuticle. Spectrochim Acta A Mol Bio Spectrosc 2020; 224: 117460.

14. Tiernan H, Byrne B, Kazarian SG. ATR-FTIR spectroscopy and spectroscopic imaging for the analysis of biopharmaceuticals. Spectrochim Acta A Mol Bio Spectrosc 2020; 241: 118636.

15. Durak T, Depciuch J. Effect of plant sample preparation and measuring methods on ATR-FTIR spectra results. Environ Exp Bot 2020; 169: 103915.

16. Muhammad S, Wuyts K, Nuyts G, De Wael K, Samson R. Characterization of epicuticular wax structures on leaves of urban plant species and its association with leaf wettability. Urban For Urban Green 2020; 47: 126557.

17. Ordoudi SA, Papapostolou M, Kokkini S, Tsimidou MZ. Diagnostic potential of FTIR fingerprinting in botanical origin evaluation of Laurus nobilis L. essential oil is supported by GC-FID-MS data. Molecules 2020; 25(3): 583. 
18. Skotti E, Pappas C, Kaiafa M, Lappa IK, Tsitsigiannis DI, Giotis C, et al. Discrimination and quantification of aflatoxins in Pistachia vera seeds using FTIR-DRIFT spectroscopy after their treatment by Greek medicinal and aromatic plants extracts. Food Science and Engineering 2020; 1(1): 45-57.

19. Palacio S, Aitkenhead M, Escudero A, Montserrat-Martí G, Maestro $M$, Robertson AJ. Gypsophile chemistry unveiled: Fourier transform infrared (FTIR) spectroscopy provides new insight into plant adaptations to gypsum soils. PLoS One 2014; 9(9): e107285.

20. Nikalje GC, Kumar J, Nikam TD, Suprasanna P. FT-IR profiling reveals differential response of roots and leaves to salt stress in a halophyte Sesuvium portulacastrum (L.) L. Biotechnol Rep 2019; 23: e00352.

21. Paiva EAS. Are calcium oxalate crystals a dynamic calcium store in plants? New Phytol 2019; 223(4): 1707-11.

22. Escudero A, Palacio S, Maestre FT, Luzuriaga AL. Plant life on gypsum: a review of its multiple facets. Biol Rev 2015; 90(1): 1-18.

23. Rosa-Tilapa D, Maceda A, Terrazas T. Characterization of biominerals in Cacteae species by FTIR. Crystals 2020; 10(6): 432.

24. Skinner HCW. Biominerals. Mineral Mag 2005; 69(5): 621-41.

25. Davis PH. Flora of Turkey and the East Aegean Islands Vol. I-IX. Edinburgh: Edinburgh University Press; 1965-1985.

26. Davis PH, Mill RR, Tan K. Flora of Turkey and the East Aegean Islands (Suppl. 1) Vol. X. Edinburgh: Edinburgh University Press; 1988.

27. Ekim T, Koyuncu M, Vural M, Duman H, Aytaç Z, Adıgüzel N. Red data book of Turkish plants (Pteridophyta and Spermatophyta). Turkish Association for the Conservation of Nature \& Van Centennial University. Ankara: Barışcan Publishing; 2000.

28. Richards L. Diagnosis and improvement of saline and alkali soils. United States Salinity Laboratory. Agriculture Handbook. Washington: U.S. Department of Agriculture Publishing; 1954.

29. Gee GW, Bauder JW. Partical-size analysis. Klute A, editor. Methods of Soil Analysis. Part 1. Physical and Mineralogical Methods. USA: SSSA Press; 1986. p. 383-411.

30. Bower CA, Reitemeier RF, Fireman M. Exchangeable cation analysis of saline and alkali soils. Soil Sci 1952; 73(4): 251-62.

31. Porta J. Técnicas y Experimentos en Edafologia. Barcelona: Col.legi Oficial d'Enginyers Agrònoms de Catalunya; 2005.

32. Nedyalkova L, Lothenbach B, Renaudin G, Mäder U, Tits J. Effect of redox conditions on the structure and solubility of sulfur-and selenium-AFm phases. Cem Concr Res 2019; 123: 105803.

33. Ashfaq MY, Al-Ghouti MA, Da'na D, Qiblawey, H, Zouari N. Effect of concentration of calcium and sulfate ions on gypsum scaling of reverse osmosis membrane, mechanistic study. J Mater Res Technol 2020; 9(6): 13459-73.

34. Jha MK, Van Nguyen N, Lee JC, Jeong J, Yoo JM. Adsorption of copper from the sulphate solution of low copper contents using the cationic resin Amberlite IR 120. J Hazard Mater 2009; 164(2-3): 94853.

35. Huang Y, Wang L, Chao Y, Nawawi DS, Akiyama T, Yokoyama T, Matsumoto $Y$. Analysis of lignin aromatic structure in wood based on the IR spectrum. J Wood Chem Technol 2012; 32(4): 294-303.

36. Boeriu CG, Bravo D, Gosselink RJ, Van Dam JE. Characterisation of structure-dependent functional properties of lignin with infrared spectroscopy. Ind Crops Prod 2004; 20(2): 205-18.

37. Sonker AK, Rathore K, Teotia AK, Kumar A, Verma V. Rapid synthesis of high strength cellulose-poly (vinyl alcohol) (PVA) biocompatible composite films via microwave crosslinking. J Appl Polym Sci 2019; 136(17): 47393.
38. Bolukbasi A, Kurt L, Palacio S. Unravelling the mechanisms for plant survival on gypsum soils: an analysis of the chemical composition of gypsum plants from Turkey. Plant Biol 2016; 18(2): 271-79.

39. Kayabaş A, Kurt A. Is the substrate an important factor in the investigation of gypsophile endemism? Proceedings of the 2 nd International Symposium on Biodiversity Research; 2020 November 18-20; Rize, Turkey. pp. 189-207.

40. Duvigneaud P, Denaeyer-De Smet S. Essai de classification chimique (éléments minéraux) des plantes gypsicoles du bassin de l'Ebre. Bulletin de la Société Royale de Botanique de Belgique 1968; 101: 279-91.

41. He H, Bleby TM, Veneklaas EJ, Lambers H, Kuo J. Precipitation of calcium, magnesium, strontium and barium in tissues of four Acacia species (Leguminosae: Mimosoideae). PLoS One 2012; 7(7): e41563.

42. Mota JF, Sola AJ, Dana ED, Jiménez-Sánchez ML. Plant succession in abandoned gypsum quarries in SE Spain. Phytocoenologia 2003; 33(1): 13-28.

43. Palacio S, Escudero A, Montserrat-Martí G, Maestro M, Milla R, Albert MJ. Plants living on gypsum: Beyond the specialist model. Ann Bot 2007; 99(2): 333-43.

44. Baize D. Guide des analyses courantes en pédologie. Paris: Inra Press; 1988.

45. Gharaibeh MA, Albalasmeh AA, Pratt C, El Hanandeh A. Estimation of exchangeable sodium percentage from sodium adsorption ratio of salt-affected soils using traditional and dilution extracts, saturation percentage, electrical conductivity, and generalized regression neural networks. Catena 2021; 205: 105466.

46. Paliwal KV, Gandhi AP. Effect of salinity, SAR, Ca: Mg ratio in irrigation water, and soil texture on the predictability of exchangeable sodium percentage. Soil Sci 1976; 122(2): 85-90.

47. Frenkel $\mathrm{H}$, Alperovitch $\mathrm{N}$. The effect of mineral weathering and soil solution concentration on ESR-SAR relationships of arid and semiarid zone soils from Israel. J Soil Sci 1984; 35(3): 367-72.

48. Rengasamy P, Greene RSB, Ford GW, Mehanni AH. Identification of dispersive behaviour and the management of red-brown earths. Soil Res 1984; 22(4): 413-31.

49. Ghafoor A, Muhammed S, Ahmad N, Mian MA. Indices for the estimation of ESP from SAR of soil solution. Pak J Sci 1988; 39:40.

50. Mohamed DM, Ibrahim SI, Elamin EA. Variability and correlation between exchangeable sodium percentage and sodium adsorption ratio in Vertisols of Sudan. Commun Soil Sci Plant Anal 2008; 39(19-20): 2827-38.

51. Seilsepour M, Rashidi M, Khabbaz BG. Prediction of soil exchangeable sodium percentage based on soil sodium adsorption ratio. Am Eurasian J Agric Environ Sci 2009; 5(1): 1-4.

52. Chi CM, Zhao CW, Sun XJ, Wang ZC. Estimating exchangeable sodium percentage from sodium adsorption ratio of salt-affected soil in the Songnen Plain of Northeast China. Pedosphere 2011; 21(2): 271-76.

53. Hazelton P, Murphy B. Soil chemical properties. Interpreting soil test results? What do all the numbers mean? Australia; 2007. p. 106-13.

54. Northcote KH, Skene JKM. Australian soils with saline and sodic properties. Canberra: Csiro Press; 1972.

55. Taşdelen K, Demir Y. Determination of salinity and sodicity conditions of rice growing areas with geographical information systems in Terme Plain. Anadolu Journal of Agricultural Sciences 2020; 35(2): 175-84. 